at the same time as the Columbus Celebrations. The meeting will be concerned with the main meteorological problems relating to navigation, with particular reference to the Mediterranean, and the principal themes will be : the vertical distribution of humidity in the air over the sea and over coastlines; the genesis of fogs and visibility at sea; winds at sea and over the coast and their influence on wave motion; and other relationships between the physies of the atmosphere and the physics of the sea. All meteorologists and oceanographers are invited to participate. Further details can be obtained from the Istituto Geofisico e Geodetico dell' Università, via Balbi 5, Genoa.

\section{University of Sheffield: Appointments}

THE following appointments in the University of Sheffield have been announced: Dr. R. Wheeler Haines, to be senior lecturer in anatomy; G. C. Briggs and W. Johnson, to be lecturers in mechanical engineering; Dr. R. P. N. Jones and M. L. Meyer, to be lecturers in the Postgraduate School of Applied Mechanics.

\section{University of Aberdeen}

AT a graduation ceremony held in the University of Aberdeen on July 12, the degree of Ph.D. was conferred on the following for the theses mentioned: W. C. Bain ("The Propagation of Radio Waves of Very Low Frequency"); Miss M. I. Chalmers ("Protein Digestion and Metabolism in relation to Level of Nutrition") ; T. L. Dodsworth ("An Investigation into the Feeding of Beef Cattle with particular reference to the Substitution of Crass Silage for Root Crops"); Miss G. M. Ellinger ("Studies of Factors affecting Bone Development in Rats and Chicks"); K. El Shazly ("Some Studies on Protein Metabolism in the Rumen") ; O. C. Farquhar ("The Geology of the Arnage District: A Study of Poly. metamorphism") ; E. A. Fitzpatrick ("A Study of the Effect of the Nature of the Parent Material on the Development of the Soil Profile with Special Reference to an Area in North-East Scotland"); D. A. Jones ("The Production and Properties of Artificial Crystals") ; J. D. Lawson ("Scale Models in Hydraulic Engineering") ; F. H. C. Marriott ("The Analysis and Interpretation of Multiple Measurements") ; P. A. Orkin ("Studies on Breathing and the Aspiratory Heart of Elasmobranchs") ; W. Paul ("The Inter-action of Radiation and Matter"); E. A. D. White ("The Hydrothermal Crystallization of Lithium Aluminosilicates").

Institution of Electrical Engineers : Awards

THE Council of the Institution of Electrical Engineers has made the following award of premiums for papers read or accepted for publication during the session 1950-51. Group A : Kelvin Premium: B. Adkins; John Hopkinson Premium: R. J. Clayton, Dr. D. C. Espley, G. W. S. Griffith and J. M. C. Pinkham. Group B, Non-Section Premiums : Llewellyn B. Atkinson Premium: J. H. Miason; Extra Premium: H. F. Church; Measurements Section Premiums: Silvanus Thompson Premium: Dr. A. H. M. Arnold ; Mather Premium: J. G. Yates, D. H. Lucas and D. L. Johnston; Extra Premiums : E. H. Cooke-Yarborough and E. W. Pulsford; H. H. Rosenbrock and J. R. Tagg; Dr. D. Taylor, J. Sharpe and W. Abson; Humphry M. Smith; J. R. Boundy and S. A. Bergen; O. I. Butler; Radio Section Premiums: Duddell Premium: P. A. T. Bevan and H. Page; Ambrose Fleming Premium: Dr.
J. A. Saxton, G. W. Luscombe and G. H. Bazzard Extra Premiums : E. A. Nind and E. MeP. Leyton Caradoc Williams; Dr. L. Essen; W. S. Melville R. W. Douglas and Dr. E. G. James ; H. B. Rantzen, F. A. Peachey and C. Gunn-Russell; D. G. Kiely, Instr. Lieut. A. E. Collins and G. S. Evans; Dr. A. W. Lines, G. R. Nicoll and Mrs. A. M. Woodward; Supply Section Premiums: Sebastian de Ferranti Premium : H. Leyburn and C. H. W. Lackey ; John Snell Premium: T. F. Monahan; Extra Premium: A. C. H. Frost and W. Brittlebank; Utilization Section Premiums: Crompton Premium: M. J. J. Cronin; Swan Premium: W. D. Chesterman, D. R. Glegg, G. T. Peck and A. J. Meadoweroft ; Extra Premium: T. H. Petch. Group C: Heaviside Premium: Dr. G. G. Macfarlane and Mrs. A. M. Woodward; Paris Exhibition (1881) Premium: D. B. Hogg; Oversea Premium for Students and Graduates: G. W. Donaldson; Students' Premiums : C. R. Bates ; R. W. Gee ; K. F. Tee ; J. C. Shaw ; P. D. Aylett; B. Berger; D. Bolton; E. J. R. Hardy ; I. J. Shelley ; D. S. Williams.

\section{Announcements}

The Alvarenga Prize for 1951 of the College of Physicians of Philadelphia has been awarded to Dr. George W. Thorn, Hersey professor of the theory and practice of physic, Harvard University Medical School, for his outstanding contributions to our knowledge of the role of the adrenal cortex in health and disease.

ScIEnTIFIC Report Series No. 13, "The Structure and Configuration of Sucrose", published by Sugar Research Foundation, Inc., New York (pp. 40; June 1950; free), contains an interesting historical review of the subject, with full references to literature. The text is by Dr. I. Levi and Prof. C. B. Purves.

British Standards Specifications Nos. 628-32 and $650-56$ (1950) on vegetable oils, and 684 (1950) on methods of analysis of oils and fats, give the specifications of several vegetable oils, and standard methods of analysis of these, respectively. The first costs $6 s$. net and the other two 7s. 6d. net, in each case postage paid, obtainable from the British Standards Institution, Sales Department, 24 Victoria Street, London, S.W.I.

A symposium entitled "Chemical Shortages and the Efficient Use of Processing Solutions" has been arranged by the Scientific and Technical Group of the Royal Photographic Society, in collaboration with the British Kinematograph Society, and will be held on October 3 at Film House, Wardour Street, W.1, starting at 7.15 p.m. Particulars can be obtained from the honorary secretary of the Group (Mr. D. H. O. John, c/o May and Baker, Ltd., Dagenham, Essex).

No. 9 of the Reader's Guides, New Series, published by the County Libraries Section of the Library Association (Chaucer House, Malet Place, London, W.C.1), deals with "Chemical Technology" and can be obtained from the Publications Secretary of the County Libraries Section of the Library Association, County Library, County Hall, Trent Bridge, Nottingham (price $4 d$.), or free of charge through county or municipal libraries. This guide contains a classified list of books dealing with various aspects of chemical technology, including prices, which should be very useful to librarians of research institutions, college and school librarians, and others, as well as to public library officials. 